\title{
FACTORS THAT INFLUENCE ZAMBIAN HIGHER EDUCATION LECTURER'S ATTITUDE TOWARDS INTEGRATING ICTS IN TEACHING AND RESEARCH
}

\author{
Douglas Kunda $(\mathbb{D}$, Christopher Chembe $\mathbb{D}$, George Mukupa $(\mathbb{D}$ \\ Mulungushi University (Zambia) \\ dkunda@mu.edu.zm,cchembe@mu.ac.zm,gmukupa@mu.ac.zm
}

Received October 2017

Accepted June 2018

\section{Abstract}

This paper investigates factors that influence Zambian higher education lecturer's attitude towards integrating ICTs in research and teaching. To determine these factors, we used online administered survey with a total of 163 respondents from public and private higher education institutions in Zambia. Quantitative data analysis based on descriptive and inferential statistics was used in this study. Inferential analysis was employed to investigate the relationships among variables using Pearson correlation analysis and completely randomized design. The results revealed that lack of adequate Internet bandwidth is among the major barrier or obstacle for assimilating ICTs in research and teaching for Zambian higher education lecturers. Additionally, training lecturers on the use of ICTs e.g. email, PowerPoint presentations, electronic boards and its advantages is the most important incentive to motivate lecturers to incorporate ICTs in research and teaching. Therefore, this study contributes to literature on factors that influence higher education lecturers' attitude towards integrating ICTs in research and teaching. This study also demonstrates a positive correlation between the important factors that influence lecturers in integrating ICTs in research and teaching.

Keywords - Attitude, Lecturers, Technology, Teaching and research, Integrating ICTs, Zambia.

\section{Introduction}

There have been efforts made to encourage students and lecturers in Universities in Africa to utilize Information Communication Technologies (ICTs) tools for research and teaching, nonetheless results usage is lacking (Danner \& Pessu, 2013; Eze, Awa, Okoye, Emecheta \& Anazodo, 2013; Ng'ambi, Brown, Bozalek, Gachago \& Wood, 2016). This can be seen in few research outputs from universities in Africa as well as poor universities ranking when compared to universities in other parts of the world (Lages, Patt \& Shepelyansky, 2016; Okorie, 2013). Recently, National Research and Education Networks (NRENs) have been introduced to provide various opportunities for researchers including increased Internet bandwidth, availability of resources through e-libraries and research collaboration. In addition, the NRENs provide federated identity service to member institutions through Education Roaming (Eduroam) as well as high performance computing coupled with cloud computing (Mkandawire, 2013). Eduroam provides connectivity to the Internet where the service is deployed for every user registered in the member institution within the country as well as outside the country with no charge to the user (Chembe, Kunda \& Simfukwe, 2014). Nevertheless, some learning institutions have not taken advantage of these opportunities instead many learners and staff are using the Internet for personal business such as chatting on social media like Facebook, Tweeter and watching YOUTUBE videos. 
A consortium of three public Universities in Zambia, that is the University of Zambia, Copperbelt University and Mulungushi University came together to collaborate and set up the Zambian Educational and Research Network (ZAMREN) as a not for profit association. The reason for forming ZAMREN was to enable provision of inter-institutional connectivity and collaboration among Zambian research and educational institutions. In addition, ZAMREN was mandated to connect these local institutions to the Regional Research and Education Network (RREN) in Southern and Eastern Africa in collaboration with UbuntuNet (www.ubuntunet.net). This allowed ZAMREN to extend its reach to other NRENs in Africa as well as the rest of the World (Kunda \& Khunga, 2014). ZAMREN became operational in June 2012 initially with the three public Universities, by the end of 2016 the membership had grown to 78 education and research institutions connected to the network (Khunga \& Kunda, 2017). The introduction of ZAMREN provided opportunities for Zambian higher education institutions increase access to ICT services and products with increased Internet bandwidth, increased availability of resources such as e-libraries and collaborative research. ZAMREN also has brought significant impact on higher education institutions by improving ICT skills uptake through its technical capacity building programmes and by providing cloud computing and high-performance computing to facilitate research on big data and Internet of Things.

Regardless, some institutions of higher learning in Zambia did not utilize these opportunities because of lecturers' attitude towards ICTs and barriers for incorporating ICTs in research and teaching. It is from this preview that a study was conducted in higher institutions in Zambia to assess factors that can be used to transformation lecturer's attitude towards embracing ICTs in research and teaching. The preliminary results of the study was presented at a conference in Zambia (Kunda, 2014). In this study, the survey approach was used where online questionnaires were administered. Descriptive analysis and regression analysis were used to analyze the data for this study. Nevertheless, this study considered a small data set which was not indicative of what is pertaining in the institutions. Therefore, this study is an extension to the preliminary findings that was presented at the conference (Kunda, 2014). Hence, it is anticipated that the extensive results presented in this study can be valuable to lecturers, researchers, University Management and other policy-makers in developing strategies that would change lecturers' attitude and thus increase integration and using ICTs in research and teaching. The following research questions are explored in this work:

- What are the barriers and obstacles that lecturers face in integrating ICTs in teaching and research?

- What are the important variables that influence lecturers to encourage them to use ICTs in teaching and research?

- What are the relationships between the important variables that influence lecturers to adopt ICTs in teaching and research?

- What are the important drivers or catalysts that can be used to motivate lecturers to integrate ICTs in teaching and research?

This paper presents a research model used to assess important factors that influence Zambian higher education lecturer's attitude towards integrating ICTs in research and teaching. It deliberates on some tools and variables that higher education institutions can use in encouraging lecturers to use ICTs in research and teaching. The paper outlines the factors assessed for this study. The factors in the research model this study looks at include direct sensitization of lecturers on benefits of using ICTs in learning and research. The other factors include the use of incentives to motivate lecturers in using ICTs when conducting their research and teaching. The model illuminates how these factors can be used both indirectly and directly to improve the adjustment of attitudes on lecturers. Thus, the paper discusses the findings of a survey undertaken among four higher institutions of learning in Zambia. 


\section{Literature Review}

Compared to developed countries, developing countries are still lagging behind in integrating ICTs in research and teaching. Nevertheless, there have been new efforts by many developing nations to overcome such lagging by investing in ICT infrastructure and introducing new approaches to providing access to the Internet through NRENs (Goktas, Gedik \& Baydas, 2013; Mkandawire, 2013). Many opportunities have been provided by the introduction of NRENs to researchers and teachers through increased Internet bandwidth, availability of resources through e-libraries and collaborative research. Infrastructure wise has also not been left, for instance in Zambia, CEEC Liquid and ZESCO have installed fiber optic covering major parts of the country. Furthermore, there are lots of teaching and research open source software that can be used by institutions in teaching and research. Among commonly available open software include Learning Management Systems (LMS) e.g. Moodle, tools for capturing and podcasting lectures (Camstudion), tools for online lecture/webinars with remote participation (OpenMeetings), tools for authoring eBook and word processing (LibreOffice), tools for referencing (Zotero), integrated library systems (Koha) and interactive whiteboards. Nonetheless, there is still a gap in integrating all these ICTs in research and teaching by many institutions (Goktas et al., 2013; Keengwe, Onchwari \& Wachira, 2008; Wachira \& Keengwe, 2011).

Common barriers that affect the integration of ICTs into research and teaching have been identified by many researchers. For example, Goktas et al., (2013) grouped these barriers into internal and external barriers. Among internal barriers, beliefs and attitudes toward the use of technology in education together with the approach used in teaching mattered. Conversely, the external barriers mostly involved inadequate software and hardware as well as lack of technical support among staff and time. Following discussion outline these barriers for integrating ICTs in research and teaching:

- Lack of in-service and re-training in ICTs (Akbaba-Altun, 2006; Ertmer, Ottenbreit-Leftwich, Sadik, Sendurur \& Sendurur, 2012). This is an important barrier as there are many new and cheaper technologies being introduced on the market for research and teaching regularly. Therefore, teachers and researchers require training and re-training in these new technologies to smoothen the integration. There are also new teachers and researchers being recruited by research and educational institutions and these will require in-service training to become familiar with the technology.

- Lack of technical and appropriate administrative support (Bingimlas, 2009). Researcher and teachers find it frustrating when they try to integrate new technology in teaching then observe the technology is not performing its intended purpose. Some of these technologies do not have any supporting user manual and where user manual exist they are not well written to assist them resolve the problems. Hence, it is important to provide needed ongoing technical support to lecturers and teachers in order to motivate and encourage them to use ICTs in their work.

- Lack of adequate hardware/software and insufficient number of computers (Dionys, 2012; Pelgrum, 2001). This is problematic especially in developing nations where lack of financial resources has contributed to low investment in software and hardware. In some cases, certain institutions have adopted bring your own device (BOYD) approach whereby the institutions request students and staff to bring their own computers and laptops to class and use them connect to institutions' network. Other institutions have not adopted the BOYD approach because they introduce security risks to the institutional network.

- Lack of basic knowledge/skills in ICTs usage and integrating ICTs in research and teaching (Bingimlas, 2009; Dionys, 2012). Certain researchers and teachers are not conversant with ICTs usage and require training basic ICT skills. Others may have the ICT skills but encounter difficulties in integrating ICTs in research and teaching, for example they may not know how to convert their lecture notes in a courseware. 
- Lack of appropriate ICT infrastructure (Bingimlas, 2009; Dionys, 2012; Pelgrum, 2001). Many new technologies appearing on the market are bandwidth intense, for instance, software for capturing high quality video lectures and podcasting need huge bandwidth. Hence, this needs investment in ICT infrastructure which can be a problem for many institutions in developing nations due to lack of funds or because investment in ICTs is not a priority to them.

- Lack of appropriate course content and instructional programs (Akbaba-Altun, 2006; Pelgrum, 2001; Usluel, Mumcu \& Demiraslan, 2007). Lack of appropriate course content in ICT format is a challenge as it requires a lot of resources or work for the lecturer to digitize or convert the material that is in paper format in digital format. Some lecturers find it difficult to develop and package appropriate course content mainly because these require other ICTs skills such as graphic design that need to be learned.

- Insufficient lecturer/teacher time (Bingimlas, 2009; Goktas et al., 2013). There is not enough time for teachers and lectures to learn the needed ICT skills, design appropriate content and integrate these ICTs skills when researching and teaching. This is mainly because lecturers spend most of their time preparing lesson plans and materials through traditional way as well as busy teaching and marking scripts.

Many initiatives have been proposed to overcome such barriers by many researchers comprising offering high quality and large quantity in-service and pre-service training in ICTs (Bingimlas, 2009; Nkula \& Krauss, 2014; Yildirim, 2007). Other researchers have advocated for a deliberate policy in supporting teachers to use ICTs effectively, allocating specific units as well as personnel for peer support (Bingimlas, 2009; Mueller, Wood, Willoughby, Ross \& Specht, 2008) while others have suggested designing appropriate course content and instructional programs (Cuban, Kirkpatrick \& Peck, 2001; Yildirim, 2007) and reducing the number of courses teachers take (Bingimlas, 2009; Hew \& Brush, 2007).

Zambia is a landlocked country located in Sub-Saharan Africa and faces a lot of economic challenges with annual GDP growth rate 3.3\% in 2016. A landlocked country like Zambia pays extra transaction costs for ICT services because most of the Internet connectivity to Europe or USA is through the sea cable and therefore they have to pay transit costs to neighboring countries before they can access the sea cable (Kunda \& Khunga, 2014). According to World Bank, Zambia is lower middle income countries as it can be confirmed from the socio-economic indicators below (Work-Bank, 2017).

\begin{tabular}{|l|l|}
\hline \multicolumn{1}{|c|}{ Indicators } & \multicolumn{1}{c|}{ Values } \\
\hline Population & 16.59 million (2016) \\
\hline GDP & $\begin{array}{l}\text { \$19.55 billion (2016) } \\
\text { Annual GDP growth rate 3.3\% (2016) }\end{array}$ \\
\hline Per capita gross national income (GNI), Atlas method & $\$ 1,300(2016)$ \\
\hline Prevalence of HIV total (\% of population ages 15-49) & $12.4 \%$ \\
\hline Mobile cellular subscriptions (per 100 people) & 74.9 \\
\hline Individual using the Internet (\% of population) & 25.5 \\
\hline
\end{tabular}

Table 1. Zambia Indicators (World Bank, 2017)

\section{Research Model and Hypotheses}

There are a number of models that can be adopted and used to assess the factors that influence higher education lecturer's attitude towards ICT integration in research and teaching. Examples include the Technology Acceptance Model (TAM) (Davis, 1993) and the Delone and Mclene information system success model (Delone \& Mclean, 2004). Generally, TAM has been used to assess acceptance of ICTs for individuals, in addition, TAM is a powerful model that is used to predict user acceptance. Despite empirically documented applicability of TAM, more efforts are necessary to validate existing research 
results especially research that involve different users, technologies, and/or organizational contexts. This would extend the theoretical validity and empirical applicability of the TAM model (Escobar-Rodriguez \& Monge-Lozano, 2012). Furthermore, the TAM and the Delone and Mclene model are best suited for application in more developed contexts, this will require a lot of validation and tweaking in order to apply them to a developing country like Zambia. Donnelly, McGarr and O’Reilly (2011) proposes a useful model that can be used as a starting point for various stakeholders in education planning to integrate resources based on ICT in schools (Donnelly et al., 2011). This model suggests important descriptors for variant types of teachers and how they relate to the introduction of new ICTs in schools. However, the focus of this model is high schools and does not address the requirements of Universities that need to integrate ICTs in both teaching and research. Nkula and Krauss (2014) suggest a framework that looks at essential factors for integrating ICTs in education in developing context. However, the framework was based on the observation of processes conducted to include ICTs in rural schools of South Africa where no ICTs had been implemented before. Based on existing theoretical framework and literature on challenges of integrating ICTs in developing countries, a research model was developed (Figure 1) with eight hypotheses.

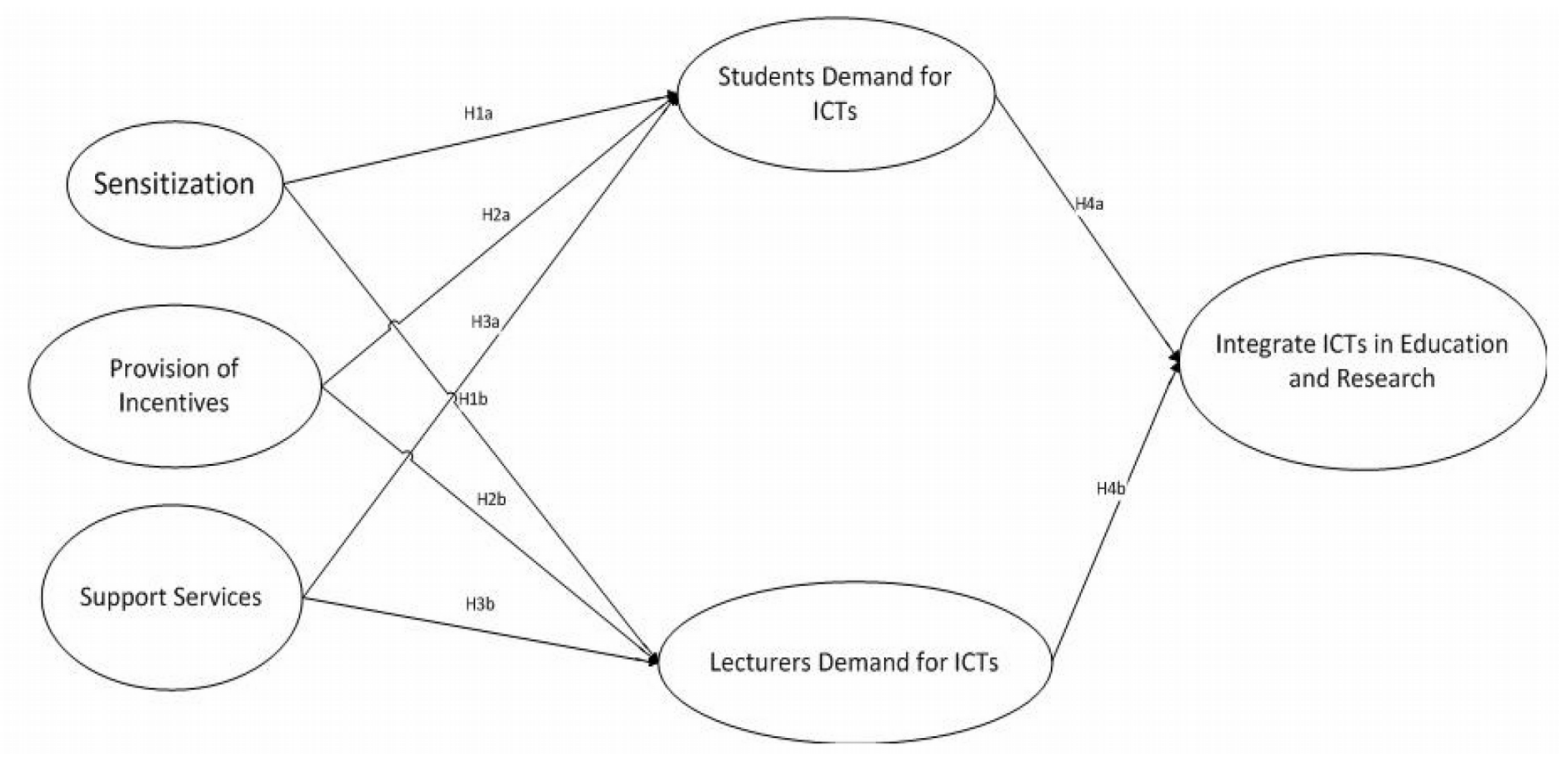

Figure 1. Research Model

\subsection{Sensitize Lecturers and Students in the Use of ICTs}

Sensitization of lecturers on the advantages of using ICTs in their work is an important factor identified in literature. There is a need to sensitize Lecturers on the benefits of integrating ICTs in research and teaching. For instance, lecturers can record videos and tutorials on concepts that are difficult to grasp for students and them available. In turn, students can watch the videos while learning at their own pace. Consequently, this would free up lecturers' time to do other duties such as research. In addition, lecturers can be sensitized on the benefits of using LMS that improves lecture and student collaboration. LMS can also be used in assessments of student performance such as marking quizzes and tests to the benefit of lecturers.

Similarly, there is need to sensitize students on the benefits of integrating ICTs in research and learning. The learning institutions should demonstrate to students the importance of using ICTs in enriching independent research and active learning. This would in turn encourage students to take responsibility for their own learning. In this way, students can act as catalysts in encouraging and demanding the use ICTs by lecturers in teaching. For instance, when students observe benefits of using ICTs in teaching by a single lecturer, they can request other lecturers who do not use ICT to follow suit. 
Therefore, we propose two hypotheses based on sensitization variables (H1a and H1b)

H1a: The greater the sensitization of lecturers in use of ICTs, the greater the demand for ICTs by lecturers

H1b: The greater the sensitization of students in use of ICTs, the greater the demand for ICTs by students

\subsection{Provision of Incentives to Lecturers and Students}

One of the motivating factors that would encourage lecturers to change their attitude towards the use of ICTs in research and teaching is the provision of incentives. There are various incentives that management of institutions can provide to lecturers. These incentives would include fitting all lecture rooms with stateof-art ICT equipment e.g. projectors, laptop, Wi-Fi, etc. Other incentives would be provision of more Internet bandwidth for research because slow Internet can demotivate them as well as provision of incentives in form finance such as prizes for lecturers who use ICTs in research and teaching.

Provision of incentives to students should act as a catalyst for them to demand the use of ICTs in learning by their lecturers. For example, availability of ICTs teaching equipment in classrooms and availability of University learning management platform will encourage students to demand lecturers to use these facilities; other incentives would be ensuring that all student hostels on campus are covered by Wi-Fi and/or Eduroam.

Therefore, we propose two hypotheses based on the provision of incentives variables (H2a and H2b)

H2a: The greater the provision of incentives to lecturers in ICTs, the greater the demand for ICTs by lecturers

H2b: The greater the provision of incentives to students in ICTs, the greater the demand for ICTs by students

\subsection{Provision of Support Services to Lecturers and Students}

Provision of ICT support services to lecturers is very important as well as assisting them on how to integrate ICTs in research and teaching. There are various support services that can be used to help lecturers, these can be through provision of help desk for launching complaints, discussion groups, websites, etc. In addition, lecturers can be provided with technical support on how to use academic systems used in faculties like LMS, Eduroam, online journal and library. Furthermore, training can be conducted for lecturers on how to use ICTs tools for research and teaching. Moreover, other support services would include advice on how to purchase ICT hardware and software and assistance on how to connect these devices to the institution networking infrastructure.

Support services to students should act as drivers of change. If students have ICTs gadgets that are working well, they can demand lecturers to use ICTs in teaching and making it easier for them to communicate with their teachers. Support services to students can be in form of help desk via emails, free phone call center, websites, discussion groups and service center where students can take their computer for configurations.

Therefore, we propose two hypotheses based on provision of support services variables ( $\mathrm{H} 3 \mathrm{a}$ and $\mathrm{H} 3 \mathrm{~b}$ )

H3a: The greater the provision of support services to lecturers in ICTs, the greater the demand for ICTs by lecturers

H3b: The greater the provision of support services to students in ICTs, the greater the demand for ICTs by students

\subsection{Demand for ICTs by Lecturers and Students}

The drivers in the research model can be defined as independent variables which have influence on the dependent variable. The dependent variable in this case is lecturer's attitude towards integrating ICTs in research and learning as noted in Figure 1. Through the model, it is shown that these drivers if properly administered can increase ICTs usage among lecturers thereby improving the standard of research and learning in universities. The independent variables can be categorized as primary and secondary drivers. Primary drivers are sensitization of lecturers and students on the use of ICTs, providing incentives to 
lecturers and students for using ICTs and providing support services to lecturers and students to enable them use ICTs more effectively. When students get the benefits of using ICTs based on primary drivers, they can demand lecturers to integrate ICTs in teaching and research. Hence, students as secondary drivers who only influence lecturer's attitude in using ICTs by demanding them to do so once they themselves understand the importance of ICTs. Therefore, primary drivers have both direct and indirect influence on the dependent variable (faculty member attitude towards ICTs usage).

Therefore, we propose two hypotheses based on provision of demand for ICTs by lecturers and students variables ( $\mathrm{H} 4 \mathrm{a}$ and $\mathrm{H} 4 \mathrm{~b})$

H4a: The greater the demand by lecturers to use ICTs, the greater the integration of ICTs by lecturers in teaching and research

H4b: The greater the demand by students to use ICTs, the greater the integration of ICTs by lecturers in teaching and research

\section{Methodology}

\subsection{Overview}

The approach used in this paper involved the use of an online administered survey that was conducted in 2015 and 2016. The online questionnaire was designed taking into account suggestions on how to create online survey (Norman, Friedman, Norman \& Stevenson, 2001). This method was adopted because it provides ways of systematically data collection and facilitates easier validation and exportation of data into data analysis software tool.

\subsection{Participants}

The population of respondents came from 4 higher learning institutions in Zambia that are members of ZAMREN (Kunda \& Khunga, 2014). The higher learning institutions considered were Mulungushi University (MU), Copperbelt University, University of Zambia (UNZA), and Zambia Centre for Account Studies (ZCAS). The institutions were purposively selected because they have a diversity of ICTs tools for research and teaching by academic staff as well as being members of ZAMREN which is an organization that provides Internet access to these institutions (Mkandawire, 2013). Cooper, Schindler and Sun (2006) argue that purposive sampling is suitable for exploratory studies when used in the early stages (Cooper et al., 2006).

It is important to select a reasonable sample size of respondents to avoid wasting resources in form of time or money required to collect data from large samples. In order to get correct and reliable results, samples should not however be small, doing so may compromise the reliability of the research outcome. The advantage of large sample sizes is that they offer less prone errors when it comes to population generalization. In order to avoid bias and instil confidence in the data captured, the sample size was calculated using Cochran formula as suggested by Barlett, Kotrlik and Higgins (2001) where n denotes the sample size as follows (Barlett et al., 2001):

$$
n=\frac{z^{2} * p(1-p)}{e^{2}}
$$

and

$e=$ the prevalence estimated tolerance error which is 0.10 or $10 \%$.

$z=$ the confidence level equal to 1.96 (Such that $\alpha=0.05$ )

Based on the population of 1,000 and Cochran formula the minimum sample size was estimated at 213. A total of 173 respondents answered the online questionnaires. 


\subsection{Data collection Instruments}

The questionnaire was designed by the primary author and peers reviewed by a statistician and a reviewer of background in ICTs. The final version was implemented using Google forms and the link created was sent to participants from both streams through their institutional emails. The institutional emails were validated through ZAMREN the service provider. The questionnaire consisted of 58 questions. The questions were subdivided into 9 categories according to the factors being investigated that were perceived to change attitude of lecturers towards the use of ICTs for research and teaching in Zambia (summarized in Table 2). Of the 58 questions, 49 were multiple choice questions with Likert-scale point of 5 indicating strength of agreement to the question in particular with 5 implying strongly agreement. The other 9 questions were open ended questions for each category to further inquire from participants on other aspects of the section which were not covered by the questions in that section. The first category comprised of 12 multiple choice questions to investigate the barrier and obstacles for lecturers to incorporate ICTs in research and teaching. The second, third and fourth categories were divided into two groups to cater for the streams mentioned above (see Table 2). Categories belonging to stream A were on the sensitization and training of lecturers, incentives for lecturers and support services that influence lecturers in integrating ICTs in teaching and research. Conversely, categories that came under stream B were on the sensitization and training of students to assimilate ICTs in research and learning, incentives for students to demand lecturers to incorporate ICTs in research and teaching, and ICT support services that would influence students to demand lecturers to incorporate ICTs in research and teaching. The difference between stream A and B for the categories above is students' demand of their lecturers to integrate ICTs tools in learning. The eighth category was concerned with factors that demonstrate that lecturers are integrating ICTs in teaching and research. Finally, the last category considered questions associated with best practices for integrating ICTs in teaching and research.

\begin{tabular}{|c|l|l|}
\hline Category & \multicolumn{1}{|c|}{ Variables } & \multicolumn{1}{c|}{ Section of Questionnaire } \\
\hline 1 & Barriers to integrate ICT & $\begin{array}{l}\text { Barriers and obstacles for lecturers to integrate ICTs in teaching and } \\
\text { learning }\end{array}$ \\
\hline 2 & $\begin{array}{l}\text { Sensitization and Training } \\
\text { of lecturers }\end{array}$ & $\begin{array}{l}\text { Sensitization and training of lecturers in use of ICTs in teaching and } \\
\text { research }\end{array}$ \\
\hline 3 & $\begin{array}{l}\text { Sensitization and Training } \\
\text { of Students }\end{array}$ & $\begin{array}{l}\text { Sensitization and training of students in use of ICTs in teaching and } \\
\text { research }\end{array}$ \\
\hline 4 & Incentives for lecturers & Incentives for lecturers to integrate ICTs in teaching and research \\
\hline 5 & Incentives for Students & $\begin{array}{l}\text { Incentives for students to demand lecturers to integrate ICTs in teaching } \\
\text { and research }\end{array}$ \\
\hline 6 & $\begin{array}{l}\text { Support services for } \\
\text { lecturers }\end{array}$ & $\begin{array}{l}\text { Support services that can influence lecturers to integrate ICTs in teaching } \\
\text { and research }\end{array}$ \\
\hline 7 & $\begin{array}{l}\text { Support services for } \\
\text { Students }\end{array}$ & $\begin{array}{l}\text { Support services that can influence students to demand lecturers to } \\
\text { integrate ICTs in teaching and research }\end{array}$ \\
\hline 8 & Outcome factors & $\begin{array}{l}\text { Factors that demonstrate that lecturers are integrating ICTs in teaching and } \\
\text { research }\end{array}$ \\
\hline 9 & Best practices & Best practices for integrating ICTs in teaching and research \\
\hline
\end{tabular}

\subsection{Data Analysis}

Data collection was performed using Google forms while analysis was done using IBM SPSS (Statistical Package for Social Sciences) (IBM, 2018). Quantitative data analysis based on inferential and descriptive statistics was used in this study. On one hand, descriptive statistics was used to calculate the mean, variance and standard deviation of each question items. On the other hand, the inferential analysis was employed to investigate the relationships among factors in consideration. Consequently, we used regression analysis to understand the multiple linear relationships among sensitization, training and usage of ICTs tools in a classroom were the F-test conducted on independent variables showed a relationship as 
a whole with significant figure less than 0.005 . In addition, Pearson correlation analysis was performed to ascertain if there was a positive correlation among any variables.

\subsection{Test of Validity and Reliability of Instruments}

The validity of the questionnaire was based on the content and construct validity to ensure that the information which is requested from the respondent covers all relevant areas and the objectives of the research.

In order to establish the validity of the instrument, SPSS was used concurrently on the information gathered from the questionnaire and comparison made thereafter to determine the quality and accuracy of the instrument. Reliability has to do with the consistency of the instrument and this was done. A measurement is regarded as reliable if it shows the same results time after time and this was achieved. This justifies that our survey is valid.

\section{Findings}

The first part of the findings presents the barriers and obstacles for lecturers to integrate ICTs in teaching using descriptive statistics. The others present descriptive statistics of the variables from research model. Then results of regression analysis and Pearson correlation analysis are presented.

\subsection{Barriers and Obstacles for Lecturers to Integrate ICTs in Teaching and Learning}

The descriptive statistics on the five-point Likert-type scale in this study of barriers and obstacles to integrate ICTs in teaching and learning are presented in Table 3.

The results indicate that lack of adequate Internet bandwidth $($ Mean $=4.04)$ had the highest mean score and this is despite ZAMREN providing increased Internet bandwidth to higher education institution. This suggests that the Internet bandwidth provided by ZAMREN is not adequate to meet the needs of lecturers and students. This also indicates that Internet costs in Zambia is high. Bandwidth is a challenge in other developing countries especially Africa (Mtebe \& Raisamo, 2014; Mtebe \& Raphael, 2017; Tarus, Gichoya \& Muumbo, 2015). In order to address this challenge higher education institutions in Zambia should adopt techniques that can optimize the available Internet bandwidth such as caching, cleaning up computers, quality of service (QoS), channel bonding and finding best DNS name servers. Investing in ICT infrastructure that support caching can optimize the Internet bandwidth by allowing the local servers to save resources such as videos that were downloaded from the Internet so that other users requiring the same resource can download it from the local network. Channel bonding can aggregate two or more ports to act as if they were one thus effectively doubling the bandwidth. A lot of computer applications use the Internet without the user knowing. For example, to update the operating system, email spamming, security update, media play pop-ups. Therefore, Internet bandwidth can be increased by cleaning up all computers on the network using anti-spam and anti-virus software. QoS monitoring tools can be installed on the network to control and prioritize bandwidth hogging applications such as video chats, plays online games, torrents files, or user services like Netflix.

Lack of adequate hardware (insufficient number of computers) for lecturers and students (Mean $=3.78$ ) and lack of appropriate ICT infrastructure (Mean $=3.78$ ) were the next important barrier and obstacle to integrating ICTs in teaching and learning. Procurement of ICT hardware and software is expensive in developing countries because of transportation costs and high taxation. The Government should consider reducing taxation on importation of ICT hardware, software and ICT services such as the Internet in order to encourage lecturers in higher education institutions to integrate ICTs in research and teaching. Other barriers to integrating ICT include lack of adequate software for lecturers and students, lack of technical support, lack of suitable ICT administrative support, lack of knowledge/skills for ICT integration in teaching, learning and research, lack of in-service and re-training in ICTs, lack of basic ICT knowledge/skills. Lack of appropriate course content and instructional programs (Mean $=2.93$ ) and insufficient time (lack of time) to use ICTs (Mean $=2.84$ ) were lowest scored. 
We realize that all the variables assessed are negatively skewed except for Lack of appropriate course content and instructional programs and insufficient time (lack of time) to use ICTs. The duo was among the least factors influencing lecturers to integrate ICTs in teaching and research. Among other barriers found were Lecturers overloaded with too many courses to teach, the unwillingness by some lecturers to use ICT materials, insufficient ICT qualified staff, inadequate LCD projectors in the School Departments, poor and unreliable Internet connectivity, limited financial resources and negative attitude towards usage of ICT. Respondents also indicate the following barriers; lack of good ICT policies for higher education institutions; lack of financial support to implement existing ICT policies; high cost of hardware and software for lecturers and students; Internet is very expensive in Zambia; load shedding of power or electricity; some administrators and lecturers lack interest in ICT as they feel it's not their area of specialization. It is interesting to note that some of the barriers brought out by the respondents were specific problems to developing countries for example Internet being very expensive and load shedding of power or electricity.

\begin{tabular}{|l|r|r|r|r|r|}
\hline Variables Assessed & \multicolumn{1}{|c|}{ N } & \multicolumn{1}{|c|}{ Mean } & Std. Deviation & Variance & Skewness \\
\hline Lack of in-service and re-training in ICTs & 152 & 3.57 & 1.188 & 1.412 & -0.56 \\
\hline Lack of technical support & 151 & 3.75 & 1.166 & 1.360 & -0.84 \\
\hline Lack of appropriate administrative support & 151 & 3.48 & 1.26 & 1.585 & -0.49 \\
\hline $\begin{array}{l}\text { Lack of adequate hardware (insufficient number of } \\
\text { computers) for lecturers and students }\end{array}$ & 151 & 3.78 & 1.375 & 1.892 & -0.83 \\
\hline Lack of adequate software for lecturers and students & 150 & 3.70 & 1.309 & 1.715 & -0.77 \\
\hline Lack of basic ICT knowledge/skills & 152 & 3.16 & 1.393 & 1.939 & -0.15 \\
\hline $\begin{array}{l}\text { Lack of knowledge/skills for ICT integration in } \\
\text { teaching, learning and research }\end{array}$ & 148 & 3.49 & 1.187 & 1.408 & -0.45 \\
\hline Lack of appropriate ICT infrastructure & 150 & 3.78 & 1.236 & 1.528 & -0.82 \\
\hline Lack of adequate Internet bandwidth & 149 & 4.04 & 1.144 & 1.309 & -1.07 \\
\hline Lack of ICT ready classrooms & 149 & 3.68 & 1.331 & 1.771 & -0.64 \\
\hline $\begin{array}{l}\text { Lack of appropriate course content and instructional } \\
\text { programs }\end{array}$ & 147 & 2.93 & 1.33 & 1.768 & 0.03 \\
\hline Insufficient time (lack of time) to use ICT & 148 & 2.84 & 1.46 & 2.137 & 0.15 \\
\hline
\end{tabular}

Table 3. Barriers and Obstacles to integrate ICTs in teaching and learning

\subsection{Sensitization and Training of Lecturers in Use of ICTs in Teaching and Research}

The descriptive statistics on the five-point Likert-type scale in this study of the research model are presented in Table 4.

The study indicates that training lecturers on the use of ICTs e.g. email, PowerPoint presentations, electronic boards and its advantages can help lecturers integrate ICTs in teaching and research has the highest acceptance level of 4.27. This suggests that lecturers in Zambia are not using email, PowerPoint presentations and electronic boards. In order to use PowerPoint in teaching there is need to procure projectors. It is expensive in a developing country like Zambia to install projectors and electronic boards in all lecture room and therefore higher education institution needs to invest in these ICT equipments to encourage lecturers to integrate them in teaching and research. Training lecturers on the use of ICTs was followed by training lecturers on the use of electronic learning management system e.g. Moodle and its advantages (acceptance level of 4.25). The lowest variable was training lecturers on the use of Eduroam (education roaming) and its advantages can help lecturers integrate ICTs in teaching and research (acceptance level of 4.12). The lower acceptance level on the use of Eduroam and its advantages indicates that although ZAMREN offers Eduroam to all its members, respondents may not be aware of this facility of free Internet connectivity when visiting institutions wherever Eduroam is deployed within the country and around the world. 


\begin{tabular}{|c|c|c|c|c|c|}
\hline Variables Assessed & $\mathbf{N}$ & Mean & $\begin{array}{l}\text { Std. } \\
\text { Error }\end{array}$ & $\begin{array}{c}\text { Std. } \\
\text { Deviation }\end{array}$ & Variance \\
\hline $\begin{array}{l}\text { Sensitization workshops for lecturers on advantages of integrating } \\
\text { ICT in teaching and research can help lecturers integrate ICTs in } \\
\text { teaching and research. }\end{array}$ & 143 & 4.17 & 0.091 & 1.173 & 1.083 \\
\hline $\begin{array}{l}\text { Training lecturers on the use of ICTs e.g. email, PowerPoint } \\
\text { presentations, electronic boards and its advantages can help } \\
\text { lecturers integrate ICTs in teaching and research. }\end{array}$ & 143 & 4.27 & 0.085 & 1.042 & 1.021 \\
\hline $\begin{array}{l}\text { Training lecturers on the use of electronic learning management } \\
\text { system e.g. Moodle and its advantages can help lecturers integrate } \\
\text { ICTs in teaching and research. }\end{array}$ & 144 & 4.25 & 0.093 & 1.238 & 1.113 \\
\hline $\begin{array}{l}\text { Training lecturers on the use of electronic journals, e-library, } \\
\text { Google scholar, Internet search and their advantages can help } \\
\text { lecturers integrate ICTs in teaching and research. }\end{array}$ & 139 & 4.20 & 0.099 & 1.350 & 1.162 \\
\hline $\begin{array}{l}\text { Training lecturers on the use of eduroam (education roaming) and } \\
\text { its advantages can help lecturers integrate ICTs in teaching and } \\
\text { research. }\end{array}$ & 140 & 4.12 & 0.089 & 1.100 & 1.049 \\
\hline
\end{tabular}

Table 4. Sensitization and training of lecturers in use of ICTs in teaching and research

Respondents also indicated measures including training lecturers on peer reviewed e-journals can help; education tours for lecturers to other higher learning institutions, integrating ICTs in teaching and research; holding ICT workshops at least 3 times in a semester; sensitization on the use of statistical software and special training for newly installed systems/projects; training on research collaboration; providing ICT equipment for lecturers to practice on; policies that will ensure that ICT's are adopted easily; basic training on how to use certain computer equipment; lecturers should be trained in ways of effectively guiding students in their research; in service training focusing on ICTs; lecturers need to be sensitized on the importance of software that deter students from plagiarism as one of the advantages of incorporating ICT; and lecturers should be sensitized that ICT is a cross cutting area in this century.

\subsection{Sensitization and Training of Students in Use of ICTs in Teaching and Research}

The descriptive statistics on the five-point Likert-type scale in this study of the research model are presented in Table 5.

\begin{tabular}{|c|c|c|c|c|c|}
\hline Variables Assessed & $\mathbf{N}$ & Mean & $\begin{array}{l}\text { Std. } \\
\text { Error }\end{array}$ & $\begin{array}{c}\text { Std. } \\
\text { Deviation }\end{array}$ & Variance \\
\hline $\begin{array}{l}\text { Sensitization workshops to students on advantages of ICTs is an } \\
\text { important factor that can help students to demand for lecturers to } \\
\text { integrate ICTs in teaching and research }\end{array}$ & 143 & 4.17 & 0.092 & 1.211 & 1.100 \\
\hline $\begin{array}{l}\text { Compulsory training of students on the use of ICTs is an } \\
\text { important factor that can help students to demand for lecturers to } \\
\text { integrate ICTs in teaching and research }\end{array}$ & 147 & 4.10 & 0.100 & 1.476 & 1.215 \\
\hline $\begin{array}{l}\text { Training students on the use of learning management system (e.g. } \\
\text { Moodle) and its advantages is an important factor that can help } \\
\text { students to demand for lecturers to integrate ICTs in teaching and } \\
\text { research }\end{array}$ & 146 & 4.03 & 0.096 & 1.337 & 1.156 \\
\hline $\begin{array}{l}\text { Training students on the use of electronic journals, e-library, } \\
\text { Google scholar, Internet search and their advantages is an } \\
\text { important factor that can help students to demand for lecturers to } \\
\text { integrate ICTs in teaching and research }\end{array}$ & 147 & 4.21 & 0.085 & 1.058 & 1.029 \\
\hline $\begin{array}{l}\text { Training students on the use of eduroam (education roaming) and } \\
\text { its advantages is an important factor that can help students to } \\
\text { demand for lecturers to integrate ICTs in teaching and research }\end{array}$ & 147 & 4.14 & 0.088 & 1.151 & 1.073 \\
\hline
\end{tabular}

Table 5. Sensitization and training of students in use of ICTs in teaching and research 
It was found that training students on the use of electronic journals, e-library, Google scholar, Internet search and their advantages was the most important factor (Mean $=4.21)$ that can enable students to be catalyst and demand for lecturers to integrate ICTs in research and teaching. Training students on the use of electronic resources such as electronic journals, e-library, Google scholar and Internet search can bring transformation in the classroom as student will do research before attending a lecture. Therefore, the transformation will enable blended learning as lecturers will also be forced to use ICTs before conducting lectures and use innovate teaching methods such as flipped classroom. Training students on the use of LMS (e.g. Moodle) and its advantages was the least important factor $($ Mean $=4.03)$ that can help students to demand for lecturers to incorporate ICTs in research and teaching. It was interesting to note that all the factors assessed scored mean of greater 4 indicating that respondents found all these factors as catalysts for change lecturer's attitude towards integrating ICTs in teaching.

Other ways brought out by respondents to sensitize and training in the use of ICTs are visiting other universities abroad can motivate; revising the ICT first year courses to include a lot more programmes that will create interest in them; introduction of ICTs in primary and secondary schools; make them do presentations using power point; ICT student forums on a global stage where students in various states globally can share experiences and ideas on ICT integration in education; exposure through student tours, exchange and attachments to industries or firms that employ ICT usage; providing many ICT centers around the University; making it compulsory for students to use ICT for all academic activities e.g. all assignment should be submitted online. This means that higher learning institutions who wish to change lecturer's attitude towards integrating ICTs in teaching should also focus on these areas and use students as catalysts for change.

\subsection{Incentives for Lecturers to Integrate ICTs in Teaching and Research}

The descriptive statistics in the five-point Likert-type scale in this study of the research model are presented in Table 6.

\begin{tabular}{|c|c|c|c|c|c|}
\hline Variables Assessed & $\mathbf{N}$ & Mean & $\begin{array}{l}\text { Std. } \\
\text { Error }\end{array}$ & $\begin{array}{c}\text { Std. } \\
\text { Deviation }\end{array}$ & Variance \\
\hline $\begin{array}{l}\text { Increasing Internet bandwidth is an important incentive for } \\
\text { lecturers to integrate ICTs in teaching and research. }\end{array}$ & 143 & 4.12 & 0.099 & 1.415 & 1.190 \\
\hline $\begin{array}{l}\text { Availability of ICT equipment in lecture rooms (e.g. PowerPoint } \\
\text { projectors, electronic boards) is an important incentive for } \\
\text { lecturers to integrate ICTs in teaching and research. }\end{array}$ & 145 & 4.39 & 0.085 & 1.060 & 1.029 \\
\hline $\begin{array}{l}\text { Providing free laptop computers and software to lecturers is an } \\
\text { important incentive for lecturers to integrate ICTs in teaching and } \\
\text { research. }\end{array}$ & 143 & 3.93 & 0.113 & 1.826 & 1.351 \\
\hline $\begin{array}{l}\text { Providing financial remuneration to lecturers who integrate ICTs in } \\
\text { teaching and research is an important incentive for lecturers to } \\
\text { integrate ICTs in teaching and research. }\end{array}$ & 136 & 3.43 & 0.129 & 2.246 & 1.499 \\
\hline $\begin{array}{l}\text { Availability of electronic learning management systems e.g. Moodle } \\
\text { is an important incentive for lecturers to integrate ICTs in teaching } \\
\text { and research. }\end{array}$ & 137 & 4.23 & 0.089 & 1.088 & 1.043 \\
\hline $\begin{array}{l}\text { Availability and free access to online journals, e-library and } \\
\text { databases is an important incentive for lecturers to integrate ICTs } \\
\text { in teaching and research. }\end{array}$ & 138 & 4.42 & 0.082 & 0.917 & 0.958 \\
\hline
\end{tabular}

Table 6. Incentives for lecturers to integrate ICTs in teaching and research

The other incentives include introduction of awards and trophies for integrating ICTs in teaching and research, having reliable Internet connectivity, furnishing classrooms with ICT platform and using projectors when teaching. Lecturers need to be exposed to the work environment in organizations for them to grasp real challenges and thus broaden their deliverables to students with more practical localized solutions to ICTs development and training they give. 


\subsection{Incentives for Students to Demand for Lecturers to Integrate ICTs in Teaching and Research}

The descriptive statistics on the five-point Likert-type scale in this study of the research model are presented in Table 7.

The most important incentives for students to demand for lecturers to incorporate ICTs in research and teaching were the availability of wireless access points around campus and hostels (Mean $=4.48$ ) and availability of adequate computer laboratory for students (Mean $=4.47$ ). It was interesting to note that although increasing Internet bandwidth is an important factor to assist students effectively in learning and research, the survey indicated that it is the least important factor to be used to motivate students to demand for lecturers to incorporate ICTs in research and teaching. This indicates that what students want is to have access to the University network and electronic resources in order for them to research and study.

Other important incentives brought out by this survey include teaching students about new software together with the lecturers; percentage of free marks for assignment submitted via ICTs platform; Certificate of recognition for those who timely and efficiently use ICT for academic purposes; facilitate procurement of cheap laptops for students to use; best Student in ICT must be awarded with free laptops; having video conferences during lectures; administrative support; provision of ICTs at subsidized rates; and provide free basic computer skills lessons.

\begin{tabular}{|c|c|c|c|c|c|}
\hline Variables Assessed & $\mathbf{N}$ & Mean & $\begin{array}{l}\text { Std. } \\
\text { Error }\end{array}$ & $\begin{array}{c}\text { Std. } \\
\text { Deviation }\end{array}$ & Variance \\
\hline $\begin{array}{l}\text { Increasing Internet bandwidth for students is an important } \\
\text { incentive to motivate students to demand lecturers to integrate } \\
\text { ICTs in teaching and research }\end{array}$ & 140 & 4.28 & 0.091 & 1.152 & 1.073 \\
\hline $\begin{array}{l}\text { Availability of wireless access points around campus and hostels is } \\
\text { an important incentive to motivate students to demand lecturers to } \\
\text { integrate ICTs in teaching and research }\end{array}$ & 140 & 4.48 & 0.073 & 0.755 & 0.869 \\
\hline $\begin{array}{l}\text { Availability of ICT equipment in lecture rooms (e.g. PowerPoint } \\
\text { projectors, electronic boards) is an important incentive to motivate } \\
\text { students to demand lecturers to integrate ICTs in teaching and } \\
\text { research }\end{array}$ & 136 & 4.35 & 0.084 & 0.956 & 0.978 \\
\hline $\begin{array}{l}\text { Availability of adequate computer laboratory for students is an } \\
\text { important incentive to motivate students to demand lecturers to } \\
\text { integrate ICTs in teaching and research }\end{array}$ & 136 & 4.47 & 0.076 & 0.784 & 0.886 \\
\hline $\begin{array}{l}\text { Availability of electronic learning management systems e.g. Moodle } \\
\text { is an important incentive to motivate students to demand lecturers } \\
\text { to integrate ICTs in teaching and research }\end{array}$ & 139 & 4.26 & 0.085 & 1.005 & 1.002 \\
\hline $\begin{array}{l}\text { Availability and free access to online journals, e-library and } \\
\text { databases is an important incentive to motivate students to demand } \\
\text { lecturers to integrate ICTs in teaching and research }\end{array}$ & 142 & 4.40 & 0.077 & 0.838 & 0.915 \\
\hline
\end{tabular}

Table 7. Incentives for students to demand for lecturers to integrate ICTs in teaching and research

\subsection{Support Services that Can Influence Lecturers to Integrate ICTs in Teaching and Research}

The descriptive statistics on the five-point Likert-type scale in this study of the research model are presented in Table 8. 


\begin{tabular}{|c|c|c|c|c|c|}
\hline Variables Assessed & $\mathbf{N}$ & Mean & $\begin{array}{l}\text { Std. } \\
\text { Error }\end{array}$ & $\begin{array}{c}\text { Std. } \\
\text { Deviation }\end{array}$ & Variance \\
\hline $\begin{array}{l}\text { Setting up help desk for lecturers with mobile phone is an } \\
\text { important support service that can influence lecturers to integrate } \\
\text { ICTs in teaching and research? }\end{array}$ & 134 & 3.78 & 0.109 & 1.604 & 1.266 \\
\hline $\begin{array}{l}\text { Setting up help desk for lecturers with email is an important } \\
\text { support service that can influence lecturers to integrate ICTs in } \\
\text { teaching and research? }\end{array}$ & 134 & 3.92 & 0.097 & 1.249 & 1.118 \\
\hline $\begin{array}{l}\text { Setting up help desk for lecturers with online (web site) access is an } \\
\text { important support service that can influence lecturers to integrate } \\
\text { ICTs in teaching and research? }\end{array}$ & 132 & 3.99 & 0.093 & 1.137 & 1.066 \\
\hline
\end{tabular}

Table 8. Support services that can influence lecturers to integrate ICTs in teaching and research

Setting up help desk for lecturers with online (website) access was the most important support service that can influence lecturers to incorporate ICTs in research and teaching. The other ICT support services include setting up help desk for lecturers with email and mobile phone; ICT support staff to visit schools/ faculties and backstopping them on any other ICT issues; support staff to go around weekly and resolving ICT difficulties; provide support services in LMS e.g. Moodle and student portal; ICT clinics for lecturers; setting up extra tutorial lectures/lessons on web portals in form of videos; help desk at each campus of the University.

\subsection{Support Services that Can Influence Students to Demand Lecturers to Integrate ICTs in Teaching}

The descriptive statistics on the five-point Likert-type scale in this study of the research model are presented in Table 9.

Setting up help desk for students with online (website) access was the most important support service that can influence students to demand lecturers to incorporate ICTs in research and teaching (Mean = 4.16). The other support services include setting up help desk for lecturers with email and mobile phone; provision of ICT manuals; support staff to visit students on weekly basis; making sure that each student is computer literate; software should be available to students; help desk at each campus; student can consult staff on ICT issues; use of social media like Facebook and SMS; ICT backstopping by ICT support staff in respective schools. It is interesting to note that students are willing to receive support services using social media like Facebook as most students have a Facebook page and therefore it is easier to communicate using a method they are familiar with.

\begin{tabular}{|c|c|c|c|c|c|}
\hline Variables Assessed & $\mathbf{N}$ & Mean & $\begin{array}{l}\text { Std. } \\
\text { Error }\end{array}$ & $\begin{array}{c}\text { Std. } \\
\text { Deviation }\end{array}$ & Variance \\
\hline $\begin{array}{l}\text { Setting up help desk for students with mobile phone is an } \\
\text { important support service that can influence students to demand } \\
\text { lecturers to integrate ICTs in teaching and research }\end{array}$ & 136 & 3.88 & 0.101 & 1.384 & 1.177 \\
\hline $\begin{array}{l}\text { Setting up help desk for students with email is an important } \\
\text { support service that can influence students to demand lecturers to } \\
\text { integrate ICTs in teaching and research }\end{array}$ & 132 & 4.07 & 0.093 & 1.148 & 1.071 \\
\hline $\begin{array}{l}\text { Setting up help desk for students with online (web site) access is an } \\
\text { important support service that can influence students to demand } \\
\text { lecturers to integrate ICTs in teaching and research }\end{array}$ & 134 & 4.16 & 0.076 & 0.780 & 0.883 \\
\hline
\end{tabular}

Table 9. Support services that can influence students to demand lecturers to integrate ICTs in teaching and research

\subsection{Factors that Demonstrate that Lecturers are Integrating ICTs in Teaching and Research}

The descriptive statistics on the five-point Likert-type scale in this study of the research model are presented in Table 10. 


\begin{tabular}{|c|c|c|c|c|c|}
\hline Variables Assessed & $\mathbf{N}$ & Mean & $\begin{array}{l}\text { Std. } \\
\text { Error }\end{array}$ & $\begin{array}{c}\text { Std. } \\
\text { Deviation }\end{array}$ & Variance \\
\hline $\begin{array}{l}\text { Increased Internet usage by lecturers is an important factor that } \\
\text { demonstrates that lecturers are integrating ICTs in teaching and } \\
\text { research. }\end{array}$ & 136 & 3.61 & 0.120 & 1.943 & 1.394 \\
\hline $\begin{array}{l}\text { Increased usage of ICTs tool in classrooms (e.g. of PowerPoint } \\
\text { projectors, electronic boards) is an important factor that } \\
\text { demonstrate that lecturers are integrating ICTs in teaching and } \\
\text { research. }\end{array}$ & 135 & 4.31 & 0.082 & 0.917 & 0.958 \\
\hline $\begin{array}{l}\text { Increased number of research and publications is an important } \\
\text { factor that demonstrates that lecturers are integrating ICTs in } \\
\text { teaching and research. }\end{array}$ & 136 & 4.18 & 0.083 & 0.946 & 0.973 \\
\hline $\begin{array}{l}\text { Increased usage of learning management systems e.g. Moodle is an } \\
\text { important factor that demonstrate that lecturers are integrating } \\
\text { ICTs in teaching and research. }\end{array}$ & 133 & 4.11 & 0.088 & 1.034 & 1.017 \\
\hline $\begin{array}{l}\text { Increased usage and access to online journals, e-libraries, e- } \\
\text { databases is an important factor that demonstrate that lecturers are } \\
\text { integrating ICTs in teaching and research. }\end{array}$ & 132 & 4.20 & 0.079 & 0.831 & 0.912 \\
\hline $\begin{array}{l}\text { Increase usage of Eduroam is an important factor that } \\
\text { demonstrates that lecturers are integrating ICTs in teaching and } \\
\text { research. }\end{array}$ & 135 & 3.93 & 0.099 & 1.331 & 1.154 \\
\hline
\end{tabular}

Table 10. Factors that demonstrate that lecturers are integrating ICTs in teaching and research

Increased usage of ICTs tool in classrooms (e.g. of PowerPoint projectors, electronic boards) (Mean $=4.31)$ and increased usage and access to online journals, e-libraries, e-databases $(M e a n=4.20)$ are the most important factor that demonstrates that lecturers are integrating ICTs in teaching and research. The other important factors are an increased number of research and publications, increased usage of LMS e.g. Moodle, increased number of consultancies and reports, increased usage of Eduroam, increased Internet usage by lecturers, monthly project presentations, sending assignment to students through the Internet and online submissions.

\subsection{Best Practices for Integrating ICTs in Teaching and Research}

Finally, the study suggests that the best practices for incorporating ICTs in research and teaching are increased usage and access to online journals, e-libraries and e-databases. The other best practices include publishing papers; empowering lecturers with the whole package of ICTs facilities, implementing course objectives with a goal of making students acquire both practical and restorative knowledge other than examination and tests. This is done by incorporating expert or special lectures by persons from external institutions/organizations using power point presentations during lecture time as agents of change to address resistance from some of senior lecturers.

Now, that the main factors in the integration of ICTs in teaching and research have been identified, the next section presents the associations of variables by running the following statistical tests based on data presented from Table 3 through to Table 10.

\subsection{Regression Analysis}

We fit the model: $\hat{Y}=\alpha+\beta_{1} x_{1}+\beta_{2} x_{2}+\beta_{3} x_{3}+\beta_{4} x_{4}+\beta_{5} x_{5}+\beta_{6} x_{6}$ by assuming $e_{i} \approx N\left(0, \sigma^{2}\right)$

\section{Hypotheses:}

$H_{0}$ : There is no linear relationship between sensitization, training $\wedge$ increased ICT usage.

vs

$H_{1}$ : There is a linear relationship between sensitization, training $\wedge$ increased ICT usage. 
In Table 11 the regression statistics are given. The Multiple $\mathrm{R}$ of 0.68715 indicates a very strong positive linear relationship between sensitizations, training and increased usage of ICTs. This explains the R Square value of about $47.22 \%$ of the total increased usage in ICTs as a result of sensitizations and training alone.

The P-value of 0.00000000000000107 in Table 12 strongly suggests that, as sensitization and training are enhanced, they bring about increased usage of ICTs.

\begin{tabular}{|l|r|}
\hline \multicolumn{2}{|c|}{ Regression Statistics } \\
\hline Multiple R & 0.68715 \\
\hline R Square & 0.472177 \\
\hline Adjusted R Square & 0.45072 \\
\hline Standard Error & 0.707563 \\
\hline Observations & 129 \\
\hline
\end{tabular}

Table 11. Regression statistics on sensitizations and training against increased usage of ICTs

\begin{tabular}{|l|r|r|r|r|r|}
\hline \multicolumn{1}{|c|}{ ANOVA } & df & SS & MS & F & Significance F \\
\hline Regression & 5 & 55.08727 & 11.01745 & 22.0065 & $1.07 \mathrm{E}-15$ \\
\hline Residual & 123 & 61.57939 & 0.500645 & & \\
\hline Total & 128 & 116.6667 & & & \\
\hline
\end{tabular}

Table 12. Analysis Output of Sensitizations and Training against Increased usage of ICTs

\section{Hypotheses:}

$H_{0}$ : There is no linear relationship between providing incentives $\wedge$ increased ICT usage.

vs

$H_{1}$ : There is a linear relationship between providing incentives $\wedge$ increased ICT usage.

In Table 13 below, the regression statistics is given. The Multiple $\mathrm{R}$ of 0.756728 indicates a strong positive linear relationship between providing incentives and increased usage of ICTs. It explains the R Square value of about $57.26 \%$ for the total increased usage in ICTs being as a result of providing incentives for lecturers and students.

In Table 14, the regression ANOVA suggests that, there is a very strong positive linear relationship between provision of Incentives for lecturers and students and increased usage of ICTs. This is evidenced by the P-value far less than $5 \%$ significance level.

\begin{tabular}{|l|r|}
\hline \multicolumn{2}{|c|}{ Regression Statistics } \\
\hline Multiple R & 0.756728 \\
\hline R Square & 0.572638 \\
\hline Adjusted R Square & 0.55162 \\
\hline Standard Error & 0.639281 \\
\hline Observations & 129 \\
\hline
\end{tabular}

Table 13. Regression statistics of Incentives for lecturers and students against increased usage of ICTs

\begin{tabular}{|l|r|r|r|r|r|}
\hline \multicolumn{1}{|c|}{ ANOVA } & df & SS & MS & F & Significance F \\
\hline Regression & 6 & 66.80775 & 11.13462 & 27.24536 & $1.97 \mathrm{E}-20$ \\
\hline Residual & 122 & 49.85892 & 0.40868 & & \\
\hline Total & 128 & 116.6667 & & & \\
\hline
\end{tabular}

Table 14. Analysis of variance for Incentives for lecturers and students against increased usage of ICTs 


\begin{tabular}{|l|r|r|r|r|r|r|}
\hline & Coefficients & Standard Error & \multicolumn{1}{c|}{ Stat } & \multicolumn{1}{c|}{ P-value } & \multicolumn{1}{c|}{ Lower 95\% } & Upper 95\% \\
\hline Intercept & 0.856502 & 0.2844409 & 3.011176 & 0.003164 & 0.293423 & 1.419581 \\
\hline X Variable 1 & -0.11883 & 0.08374963 & -1.41888 & 0.158484 & -0.28462 & 0.04696 \\
\hline X Variable 2 & 0.239 & 0.0908561 & 2.630535 & 0.009624 & 0.059142 & 0.418859 \\
\hline X Variable 3 & 0.053093 & 0.0586854 & 0.904696 & 0.367409 & -0.06308 & 0.169266 \\
\hline X Variable 4 & 0.089749 & 0.04226227 & 2.123619 & 0.035722 & 0.006087 & 0.173411 \\
\hline X Variable 5 & -0.0074 & 0.0833891 & -0.08875 & 0.929426 & -0.17248 & 0.157676 \\
\hline X Variable 6 & 0.551967 & 0.10303027 & 5.357331 & $4.05 E-07$ & 0.348009 & 0.755926 \\
\hline
\end{tabular}

Table 15. Analysis Output of Incentives for lecturers and students against increased usage of ICTs

Table 15 gives the individual relationships between provision of Incentives for lecturers and students and increased usage of ICTs. We realize that all the incentives have a positive effect on increasing usage of ICTs except for increasing Internet bandwidth and availability of electronic management systems. Also, increasing Internet bandwidth for students is believed not being a very significant incentive to motivate students to demand lecturers to incorporate ICTs in research and teaching. This is because students believe that availability of wireless access points for Internet and Intranet access around campus and hostels is an important incentive to motivate students to demand lecturers to integrate ICTs in teaching and research. As long as students have access to required resources from the Intranet or learning management system they may not demand for Internet access.

Our fitted model for this case is:

$\hat{Y}=0.856502-0.11883 x_{1}+0.239 x_{2}+0.053093 x_{3}+0.089749 x_{4}-0.0074 x_{5}+0.551967 x_{6}$.

\section{Hypotheses:}

$H_{0}$ : There is no linear relationship between support services $\wedge$ increased ICT usage.

vs

\section{$H_{1}$ : There is a linear relationship between support services $\wedge$ increased ICT usage.}

In Table 16 the regression statistics is given. The Multiple $\mathrm{R}$ of 0.698323 indicates a strong positive linear relationship between providing support services and increased usage of ICTs. This explains the R Square value of about $48.77 \%$ for the total increased usage in ICTs being as a result of providing support services.

Since the Significance F statistic $=0.00000000000000127<0.05$, we have sufficient evidence to conclude that there is a linear relationship between support services and increased usage of ICTs.

\begin{tabular}{|l|r|}
\hline \multicolumn{2}{|c|}{ Regression Statistics } \\
\hline Multiple R & 0.698323 \\
\hline R Square & 0.487656 \\
\hline Adjusted R Square & 0.46225 \\
\hline Standard Error & 0.668267 \\
\hline Observations & 128 \\
\hline
\end{tabular}

Table 16. Regression statistics of Support services against increased usage of ICTs

\begin{tabular}{|l|r|r|r|r|r|}
\hline \multicolumn{1}{|c|}{ ANOVA } & df & SS & MS & F & Significance F \\
\hline Regression & 6 & 51.43243 & 8.572072 & 19.19488 & $1.27 \mathrm{E}-15$ \\
\hline Residual & 121 & 54.03632 & 0.446581 & & \\
\hline Total & 127 & 105.4688 & & & \\
\hline
\end{tabular}

Table 17. Analysis of variance for Support services against increased usage of ICTs 


\begin{tabular}{|l|r|r|r|r|r|r|}
\hline & Coefficients & Standard Error & \multicolumn{1}{c|}{ Stat } & \multicolumn{1}{c|}{ P-value } & Lower 95\% & Upper 95\% \\
\hline Intercept & 1.331486 & 0.294 & 4.528861 & $1.4 \mathrm{E}-05$ & 0.749435 & 1.913537 \\
\hline X Variable 1 & -0.10568 & 0.09233 & -1.14459 & 0.254637 & -0.28847 & 0.077111 \\
\hline X Variable 2 & 0.128905 & 0.094593 & 1.362743 & 0.175494 & -0.05837 & 0.316176 \\
\hline X Variable 3 & 0.139596 & 0.093531 & 1.492505 & 0.13817 & -0.04557 & 0.324766 \\
\hline X Variable 4 & 0.066898 & 0.097418 & 0.686716 & 0.493576 & -0.12597 & 0.259762 \\
\hline X Variable 5 & 0.006171 & 0.082205 & 0.075069 & 0.940284 & -0.15657 & 0.168917 \\
\hline X Variable 6 & 0.495679 & 0.10189 & 4.86483 & 3.49E-06 & 0.29396 & 0.697398 \\
\hline
\end{tabular}

Table 18. Multiple Regression Summary of Support services against increased usage of ICTs

All the support services have a positive linear relationship with increased usage of ICTs except for setting up help desks for lecturers with mobile phone. This is shown in Table 17..

Here,

$\hat{Y}=1.331486-0.10568 x_{1}+0.128905 x_{2}+0.139596 x_{3}+0.066898 x_{4}+0.006171 x_{5}+0.495679 x_{6}$.

Overall, we note that sensitization and training of lecturers and students in the use of ICTs can help integrate ICTs in teaching and research to a larger extent.

\subsection{Pearson Correlation Analysis}

There are very high positive correlations of $\mathbf{0 . 4 9 8 4 7 8}$ and $\mathbf{0 . 5 4 4 7 1 7}$ between training lecturers and students on the use of electronic journals, e-library, Google scholar, Internet search and their advantages and increased usage of ICT tools in classrooms (e.g. of power-point projectors, electronic boards) respectively (see Table 20).

\begin{tabular}{l}
\hline $\begin{array}{l}\text { Sensitization workshops for lecturers on advantages of integrating ICTs in teaching and research can help lecturers } \\
\text { integrate ICTs in teaching and research. }\end{array}$ \\
\hline $\begin{array}{l}\text { Training lecturers on the use of ICTs e.g. email, PowerPoint presentations, electronic boards and its advantages can } \\
\text { help lecturers integrate ICTs in teaching and research. }\end{array}$ \\
\hline $\begin{array}{l}\text { Training lecturers on the use of electronic learning management system e.g. Moodle and its advantages can help } \\
\text { lecturers integrate ICTs in teaching and research. }\end{array}$ \\
\hline $\begin{array}{l}\text { Training lecturers on the use of electronic journals, e-library, Google scholar, Internet search and their advantages } \\
\text { can help lecturers integrate ICTs in teaching and research. }\end{array}$ \\
$\begin{array}{l}\text { Training lecturers on the use of Eduroam (education roaming) and its advantages can help lecturers integrate ICTs } \\
\text { in teaching and research. }\end{array}$ \\
\hline $\begin{array}{l}\text { Sensitization workshops to students on advantages of ICTs are an important factor that can help students to } \\
\text { demand for lecturers to integrate ICTs in teaching and research. }\end{array}$ \\
\hline $\begin{array}{l}\text { Compulsory training of students on the use of ICTs is an important factor that can help students to demand for } \\
\text { lecturers to integrate ICTs in teaching and research. }\end{array}$ \\
\hline $\begin{array}{l}\text { Training students on the use of learning management system (e.g. Moodle) and its advantages is an important } \\
\text { factor that can help students to demand for lecturers to integrate ICTs in teaching and research. }\end{array}$ \\
\hline $\begin{array}{l}\text { Training students on the use of electronic journals, e-library, Google scholar, Internet search and their advantages is } \\
\text { an important factor that can help students to demand for lecturers to integrate ICTs in teaching and research. }\end{array}$ \\
\hline $\begin{array}{l}\text { Training students on the use of Eduroam (education roaming) and its advantages is an important factor that can } \\
\text { help students to demand for lecturers to integrate ICTs in teaching and research. }\end{array}$ \\
\hline $\begin{array}{l}\text { Increased usage of ICTs tool in classrooms (e.g. of PowerPoint projectors, electronic boards) is an important factor } \\
\text { that demonstrate that lecturers are integrating ICTs in teaching and research. }\end{array}$ \\
\hline
\end{tabular}

Table 19. Arrangement of variables 


\begin{tabular}{|l|l|l|l|l|l|l|l|l|l|l|}
\hline 1 & & & & & & & & & & \\
\hline 0.355803 & 1 & & & & & & & & & \\
\hline 0.372831 & 0.692039 & 1 & & & & & & & & \\
\hline 0.474099 & 0.634332 & 0.689175 & 1 & & & & & & & \\
\hline 0.413686 & 0.57655 & 0.521973 & 0.708845 & 1 & & & & & & \\
\hline 0.379917 & 0.421728 & 0.41271 & 0.484199 & 0.418471 & 1 & & & & & \\
\hline 0.228651 & 0.409228 & 0.409977 & 0.56213 & 0.525681 & 0.500638 & 1 & & & & \\
\hline 0.24334 & 0.24941 & 0.204747 & 0.359576 & 0.408348 & 0.55949 & 0.789042 & 1 & & & \\
\hline 0.227775 & 0.285932 & 0.303428 & 0.334563 & 0.329896 & 0.590106 & 0.511752 & 0.734541 & 1 & & \\
\hline 0.198913 & 0.295487 & 0.357302 & 0.404714 & 0.438656 & 0.488091 & 0.452746 & 0.525038 & 0.682868 & 1 & \\
\hline 0.195129 & 0.287564 & 0.285633 & 0.498478 & 0.298097 & 0.454625 & 0.325174 & 0.380598 & 0.544717 & 0.43819 & 1 \\
\hline
\end{tabular}

Table 20. Pearson Correlation Analysis

In summary, lack of adequate Internet bandwidth is a major barrier or obstacle for integrating ICTs in teaching and research. Training lecturers on the use of electronic learning management system e.g. Moodle and its advantages can help lecturers integrate ICTs in teaching and research. Training students on the use of electronic journals, e-library, Google scholar, Internet search and their advantages is an important factor that can help students to demand for lecturers to integrate ICTs in teaching and research. Availability of ICTs equipment in lecture rooms (e.g. power-point projectors, electronic boards) is an important incentive for lecturers to integrate ICTs in teaching and research. Setting up help desk for students with online (website) access is an important support service that can influence students to demand lecturers to integrate ICTs in teaching and research.

\subsection{Completely Randomized Design}

We now perform a one-way Analysis of variance to test whether the barriers, sensitizations, incentives and support services differ significantly in their effect on the lecturer's attitude to integrate ICTs in teaching and research.

\section{Hypotheses:}

$$
\begin{aligned}
& H_{0}: \mu_{1}=\mu_{2}=\ldots=\mu_{12} \\
& \text { vs } \quad \text { where } \mu=\text { average barrier effect } \\
& H_{1}: \mu_{i} \neq \mu_{j}, i \neq j .
\end{aligned}
$$

\begin{tabular}{|l|r|r|r|r|r|}
\hline Source of Variation & df & SS & MS & F & Significance F \\
\hline Between Groups & 11 & 194.3144 & 17.66494 & 11.63057 & $4.37 \mathrm{E}-21$ \\
\hline Within Groups & 1477 & 2243.323 & 1.518837 & & \\
\hline Total & 1488 & 2437.637 & & & \\
\hline
\end{tabular}

Table 21. Anova Table for Barrier Effect

Since the Significance F in Table 21, is far less than 5\% significance level, we have sufficient evidence to reject $H_{0}$ and hence conclude that the barriers differ significantly in their effect on the lecturer's attitude to integrate ICTs in teaching and research.

\section{Hypotheses:}

$$
\begin{aligned}
& H_{0}: \beta_{1}=\beta_{2}=\ldots=\beta_{10} \\
& \text { vs } \quad \text { where } \beta=\text { average sensitization effect } \\
& H_{1}: \beta_{i} \neq \beta_{j}, i \neq j .
\end{aligned}
$$




\begin{tabular}{|l|r|r|r|r|r|}
\hline Source of Variation & df & SS & MS & F & P-Value \\
\hline Between Groups & 9 & 4.955033 & 0.550559 & 0.507806 & 0.869664 \\
\hline Within Groups & 1137 & 1232.726 & 1.084192 & & \\
\hline Total & 1146 & 1237.681 & & & \\
\hline
\end{tabular}

Table 22. Anova Table for Sensitization Effect

Since the P-Value in Table 22 is greater than 5\% significance level, we have sufficient evidence to fail to reject $H_{0}$ and hence conclude that the sensitizations do not differ significantly in their effect on the lecturer's attitude to incorporate ICTs in research and teaching. Therefore, it is very important to consider all the ten sensitization and training variables suggested in this paper.

\section{Hypotheses:}

$$
\begin{aligned}
& H_{0}: \varphi_{1}=\varphi_{2}=\ldots=\varphi_{12} \\
& \text { vs } \quad \text { where } \varphi=\text { average incentive effect } \\
& H_{1}: \varphi_{i} \neq \varphi_{j}, i \neq j .
\end{aligned}
$$

\begin{tabular}{|l|r|r|r|r|r|}
\hline Source of Variation & \multicolumn{1}{|c|}{ df } & SS & \multicolumn{1}{c|}{ MS } & \multicolumn{1}{c|}{ F } & P-Value \\
\hline Between Groups & 11 & 122.8469 & 11.1679 & 10.12464 & $5.07 \mathrm{E}-18$ \\
\hline Within Groups & 1514 & 1670.006 & 1.103042 & & \\
\hline Total & 1525 & 1792.853 & & & \\
\hline
\end{tabular}

Table 23. Anova Table for Incentive Effect

Since the P-Value in Table 23 is less than 5\% significance level, we have sufficient evidence to reject $H_{0}$ and hence conclude that the incentives differ significantly in their effect on the lecturer's attitude to incorporate ICTs in research and teaching. This is consistent with results obtained under regression analysis above.

\section{Hypotheses:}

$$
\begin{aligned}
& H_{0}: \gamma_{1}=\gamma_{2}=\ldots=\gamma_{6} \\
& \text { vs } \quad \text { where } \gamma=\text { average support service effect } \\
& H_{1}: \gamma_{i} \neq \gamma_{j}, i \neq j .
\end{aligned}
$$

\begin{tabular}{|l|r|r|r|r|r|}
\hline Source of Variation & df & SS & MS & F & P-Value \\
\hline Between Groups & 5 & 10.80339 & 2.160677 & 1.789224 & 0.112647 \\
\hline Within Groups & 762 & 920.1953 & 1.207605 & & \\
\hline Total & 767 & 930.9987 & & & \\
\hline
\end{tabular}

Table 24. Anova Table for Support Service Effect

Since the P-Value in Table 24 is greater than 5\% significance level, we fail to reject $H_{0}$ and hence conclude that the support services do not differ significantly in their effect on the lecturer's attitude to incorporate ICTs in research and teaching.

\subsection{Validity of Statistical Tests Used}

We regressed the variables Sensitization, Training, Incentives and Support Services against usage of ICTs because these independent variables influence ICT usage. Furthermore, a correlation analysis investigates 
the strength in the relationship established by regression analysis. A One-Way ANOVA is relevant to determine whether the barriers, sensitizations, incentives and support services differ significantly in their effect on the lecturer's attitude to integrate ICTs in teaching and research.

\begin{tabular}{|r|r|r|}
\hline Cronbach's Alpha & $\begin{array}{c}\text { Cronbach's Alpha Based } \\
\text { on Standardized Items }\end{array}$ & N of Items \\
\hline .906 & .922 & 42 \\
\hline
\end{tabular}

Table 25. Reliability Statistics

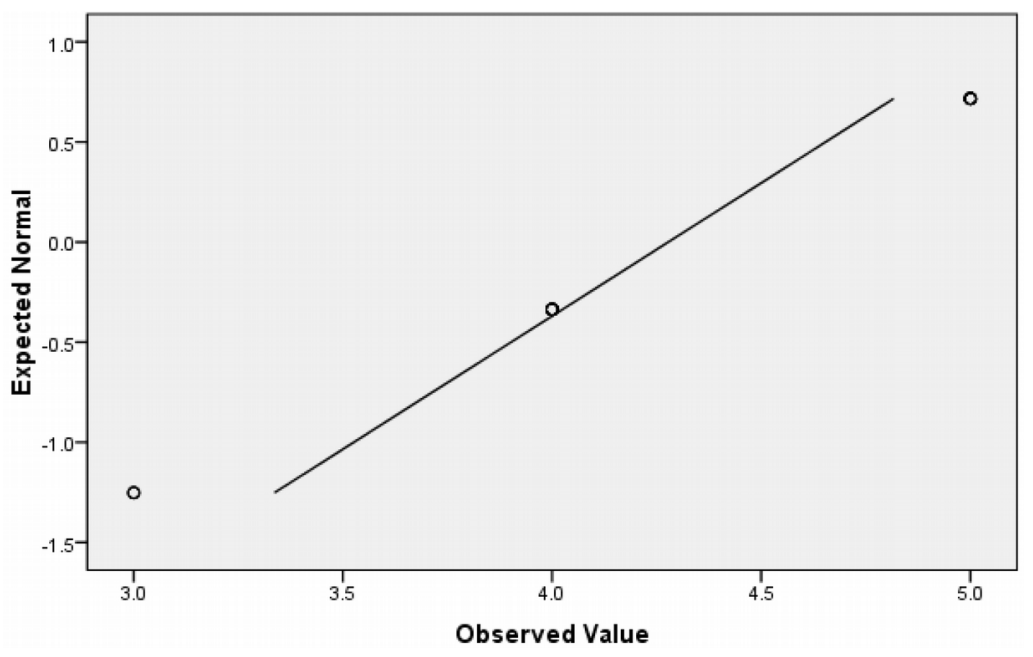

Figure 2. Normal Q-Q plot of increased usage of ICTs tool in classrooms

The Cronbach's alpha is $\mathbf{0 . 9 0 6}$ which indicates a high level of internal consistency for our Likert scale. Also, the data points are close to the diagonal line implying that our data is normally distributed. This justifies that our research is valid.

\section{Discussion of Findings}

The study had the following limitations:

- The sample size was limited;

- Limiting participants to only academic staff and students from 4 higher learning institutions; and that

- Study limited to Zambia higher learning institutions

Based on the findings, the paper recommends that the credibility and transferability of the findings be tested by conducting comparable studies across a larger sample of ZAMREN member institutions since this study was limited to 4 higher learning institutions.

The analysis of the data shown above indicates important lessons that could be brought out and can be of interest to University scholars and administrators in developing countries, despite small survey sample to draw statistically valid generalizations. Future work will be guided by lessons learnt together with other measures not reported in this paper. Regardless, the study indicates that barriers faced by some faculty members to incorporate ICT in research and teaching still exist in developing countries like Zambia. The lessons learnt include:

- Lesson one. There is need to continuously provide ICT support services to lecturers as well as assisting them to incorporate ICTs in research and teaching. Examples of support services would include setting up help desk via emails, group discussion, blogs and websites. Furthermore, 
support services would include orienting lecturers on use of academic systems used in faculties like online journals and library, LMS, etc. In addition, support can as well be in assisting lecturers on how to purchase ICT software and hardware and how to connect these devices to the institutional network.

- Lesson two. Sensitizing members of the faculties on benefits of incorporating ICTs in research and teaching. Faculty members need to be made aware of the benefits of incorporating ICTs in research and teaching. For instance, lecturers can inform of the benefits of recording difficult concepts of some topics on video and given to students. The benefit being that students will play this video and learn at their own pace. This in turn can free up lecturers' time to use on other tasks such as research. Lecturers can also be sensitized on the benefits of using LMS. Some of the benefits of using LMS include improved lecturer to student collaboration and assisting in assessments e.g. marking quizzes and tests.

- Lesson three. Sensitize students on the benefits of incorporating ICTs in research and learning. Students should be informed on the benefits of incorporating ICTs in research and learning. The learning institutions should demonstrate the importance of using ICT to students. For instance, institutions should emphasize the role ICT play in fostering independent and active learning for students and how students can take responsibility for their own learning and promote collaborative research and learning. This way, students can act as catalyst to encourage and demand lecturers to use ICTs in research and teaching.

- Lesson four. Provision of incentives to lecturers that use ICTs in research and teaching. The survey suggests providing incentives to lectures is one of the motivating factors to change their attitude towards the use of ICTs in research and teaching. There are various incentives University management can provide to lecturers including: provision of more Internet bandwidth as slow Internet can demoralize them; fitting all lecture rooms with state-of-the-art ICT equipment such as projector, interactive boards, Wi-Fi, laptop etc. Other incentives would be assisting lecturers and students to acquire personal laptops and ensuring there is a 100\% coverage of Wi-Fi and/or Eduroam on campus and student hostels. Furthermore, management could provide some form of financial incentives in terms of prizes or Labor Day awards to lecturers who incorporate ICTs in research and teaching.

- Lesson five. Continuously identify barriers for incorporating ICTs in research and teaching in the learning institutions and use suitable tools to overcome them. It is nearly impossible to completely eliminate barriers for incorporating ICTs in research and teaching. Therefore, it is imperative that these barriers are identified and explicitly addressed. Some of the methods that can be used to identify the barriers include administering online questionnaire; using discussion blogs on challenges faced by lecturers, conducting interviews with lecturers and students; monitoring use of the ICT resources to identify and interview those not using these resources. When barriers have been identified, for instance, lack of skills on packaging course materials for LMS, then training can be conducted that target this deficiency.

- Lesson six. Use incremental approach to influence higher education lecturer's attitude towards integrating ICTs in teaching and research. It is recommended that to start a small core group of faculty members and encourage them to use and incorporate ICTs in research and teaching. When the small group is sensitized and appreciate the benefit of using ICT, they can be used as champions of change to sensitize other member of staff. Involving lecturers as champions of change will generally minimize resistance to change from other lecturers. 


\section{Conclusion and Future Research}

The introduction of ZAMREN in Zambia has provided opportunities for higher education institutions to integrate ICTs in teaching and research through collaborative research, increased Internet bandwidth and availability of electronic resources such electronic journal, e-libraries and e-databases. However, some learning Institutions have not taken advantage of these opportunities because of lecturer's attitude towards ICTs and barriers to incorporating ICTs in research and teaching. This study reports the factors that influence Zambian higher education lecturer's attitude towards integrating ICTs in research and teaching. The results indicate that lack of adequate Internet bandwidth and lack of adequate hardware (insufficient number of computers) for lecturers and students as the major barrier and obstacle to integrating ICTs in teaching and learning. There is need for University management to focus on these areas and Government to consider reducing taxation on importation of ICT hardware, software and ICT services such Internet in order to address this challenge.

The study indicates that there is positive correlation between the important variables that influence lecturers to integrate ICTs in research and teaching as proposed by the research model. The study also taught us a number of lessons such as the importance of using incremental implementation through champions as agents of change. Future work will concentration on further exploration of the research model using qualitative studies. This study was conducted in Zambia and therefore further work will examine whether the model still holds in other developing countries.

\section{Declaration of Conflicting Interests}

The authors declared no potential conflicts of interest with respect to the research, authorship, and/or publication of this article.

\section{Funding}

The authors wish to thank Mulungushi University management for supporting publication of this article.

\section{References}

Akbaba-Altun, S. (2006). Complexity of integrating computer technologies into education in Turkey. Journal of Educational Technology \& Society, 9(1).

Barlett, J.E., Kotrlik, J.W., \& Higgins, C.C. (2001). Organizational research: Determining appropriate sample size in survey research. Information technology, learning, and performance journal, 19(1), 43.

Bingimlas, K.A. (2009). Barriers to the successful integration of ICT in teaching and learning environments: A review of the literature. Eurasia journal of mathematics, science \& technology education, 5(3).

Chembe, C., Kunda, D., \& Simfukwe, M. (2014). Challenges and Benefits of Educational Roaming (eduroam) Service to ZAMREN Member Institutions.

Cooper, D.R., Schindler, P.S., \& Sun, J. (2006). Business research methods (9). New York: McGraw-Hill Irwin.

Cuban, L., Kirkpatrick, H., \& Peck, C. (2001). High access and low use of technologies in high school classrooms: Explaining an apparent paradox. American educational research journal, 38(4), 813-834. https://doi.org/10.3102/00028312038004813

Danner, R.B., \& Pessu, C.O. (2013). A survey of ICT competencies among students in teacher preparation programmes at the University of Benin, Benin City, Nigeria. Journal of Information Technology Education: Research, 12, 33-49. https://doi.org/10.28945/1762

Davis, F.D. (1993). User acceptance of information technology: system characteristics, user perceptions and behavioral impacts. International journal of man-machine studies, 38(3), 475-487.

https://doi.org/10.1006/imms.1993.1022 
Delone, W.H., \& Mclean, E.R. (2004). Measuring e-commerce success: Applying the DeLone \& McLean information systems success model. International Journal of Electronic Commerce, 9(1), 31-47.

Dionys, D. (2012). Introduction of ICT and multimedia into Cambodia's teacher training centres. Australasian Journal of Educational Technology, 28(6). https://doi.org/10.14742/ajet.812

Donnelly, D., McGarr, O., \& O’Reilly, J. (2011). A framework for teachers' integration of ICT into their classroom practice. Computers \& Education, 57(2), 1469-1483.

https://doi.org/10.1016/j.compedu.2011.02.014

Ertmer, P.A., Ottenbreit-Leftwich, A.T., Sadik, O., Sendurur, E., \& Sendurur, P. (2012). Teacher beliefs and technology integration practices: A critical relationship. Computers \& Education, 59(2), 423-435. https:// doi.org/10.1016/j.compedu.2012.02.001

Escobar-Rodriguez, T., \& Monge-Lozano, P. (2012). The acceptance of Moodle technology by business administration students. Computers \& Education, 58(4), 1085-1093.

https://doi.org/10.1016/j.compedu.2011.11.012

Eze, S.C., Awa, H.O., Okoye, J.C., Emecheta, B.C., \& Anazodo, R.O. (2013). Determinant factors of information communication technology (ICT) adoption by government-owned universities in Nigeria: A qualitative approach. Journal of Enterprise Information Management, 26(4), 427-443.

https://doi.org/10.1108/JEIM-05-2013-0024

Goktas, Y., Gedik, N., \& Baydas, O. (2013). Enablers and barriers to the use of ICT in primary schools in Turkey: A comparative study of 2005-2011. Computers \& Education, 68, 211-222.

https://doi.org/10.1016/j.compedu.2013.05.002

Hew, K.F., \& Brush, T. (2007). Integrating technology into K-12 teaching and learning: Current knowledge gaps and recommendations for future research. Educational technology research and development, 55(3), 223-252. https://doi.org/10.1007/s11423-006-9022-5

IBM. (2018). SPSS Statistics Version 25. Available at: https://www.ibm.com/products/spss-statistics

Keengwe, J., Onchwari, G., \& Wachira, P. (2008). Computer technology integration and student learning: Barriers and promise. Journal of science education and technology, 17(6), 560-565.

https://doi.org/10.1007/s10956-008-9123-5

Khunga, B., \& Kunda, D. (2017). Impact of NRENs in Universities -The ZAMREN Experience. $M A N A S$ Journal of Engineering, 5(2), 13-23.

Kunda, D. (2014). Changing Faculty members' attitude towards the use of ICTs in teaching and research: the SIDS model.

Kunda, D., \& Khunga, B. (2014). Implementing national research and education Networks (NRENs) in land locked African countries: Critical success factors. In Proceedings of 7 th annual conference on Research and Education networking. Retrieved from UbuntuNet Alliance:

https://casefornrens.geant.org/Making the case/NRENs/Documents/tnc15 paper Tnc15PaperImplementingE NRENInLandlockedAfricanCountriesv3.pdf

Lages, J., Patt, A., \& Shepelyansky, D.L. (2016). Wikipedia ranking of world universities. The European Physical Journal B, 89(3), 69. https://doi.org/10.1140/epjb/e2016-60922-0

Mkandawire, S. (2013). Survival of National Research and Education Networks (NRENs) in a competitive market of Africa: A Case Study of the Zambia Research and Education Network (ZAMREN).

Mtebe, J.S., \& Raisamo, R. (2014). Investigating perceived barriers to the use of open educational resources in higher education in Tanzania. The International Review of Research in Open and Distributed Learning, 15(2). https://doi.org/10.19173/irrodl.v15i2.1803 
Mtebe, J.S., \& Raphael, C. (2017). A decade of technology enhanced learning at the University of Dar es Salaam, Tanzania: Challenges, achievements, and opportunities. International Journal of Education and Development using Information and Communication Technology, 13(2), 103-115.

Mueller, J., Wood, E., Willoughby, T., Ross, C., \& Specht, J. (2008). Identifying discriminating variables between teachers who fully integrate computers and teachers with limited integration. Computers \& Education, 51(4), 1523-1537. https://doi.org/10.1016/j.compedu.2008.02.003

Ng'ambi, D., Brown, C., Bozalek, V., Gachago, D., \& Wood, D. (2016). Technology enhanced teaching and learning in South African higher education-A rearview of a 20 year journey. British Journal of Educational Technology, 47(5), 843-858. https://doi.org/10.1111/bjet.12485

Nkula, K., \& Krauss, K.E. (2014). The integration of ICTs in marginalized schools in South Africa: Considerations for understanding the perceptions of in-service teachers and the role of training. Paper presented at the International Development Informatics Association (IDIA) conference.

Norman, K.L., Friedman, Z., Norman, K., \& Stevenson, R. (2001). Navigational issues in the design of online self-administered questionnaires. Behaviour \& Information Technology, 20(1), 37-45.

https://doi.org/10.1080/01449290010021764

Okorie, P. (2013). Preliminary Assessment of National Universities Rankings as economic indicators in Africa. European International Journal of Science and Technology, 2(8).

Pelgrum, W.J. (2001). Obstacles to the integration of ICT in education: results from a worldwide educational assessment. Computers \& Education, 37(2), 163-178. https://doi.org/10.1016/S03601315(01)00045-8

Tarus, J.K., Gichoya, D., \& Muumbo, A. (2015). Challenges of implementing e-learning in Kenya: A case of Kenyan public universities. The International Review of Research in Open and Distributed Learning, 16(1). https://doi.org/10.19173/irrodl.v16i1.1816

Usluel, Y.K., Mumcu, F.K., \& Demiraslan, Y. (2007). ICT in the learning-teaching process: Teachers' views on the integration and obstacles. Hacettepe Universitesi Egitim Fakultesi Dergisi-Hacettepe University Journal of Education, 32, 164-178.

Wachira, P., \& Keengwe, J. (2011). Technology integration barriers: Urban school mathematics teachers perspectives. Journal of science education and technology, 20(1), 17-25. https://doi.org/10.1007/s10956-010-9230-y

Work-Bank. (2017). Country Data Sheets, Zambia. Available at: https://data.worldbank.org/country/zambia

Yildirim, S. (2007). Current utilization of ICT in Turkish basic education schools: A review of teacher's ICT use and barriers to integration. International Journal of Instructional Media, 34(2), 171.

Published by OmniaScience (www.omniascience.com)

Journal of Technology and Science Education, 2018 (www.jotse.org)

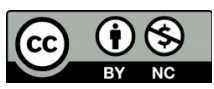

Article's contents are provided on an Attribution-Non Commercial 4.0 Creative commons International License.

Readers are allowed to copy, distribute and communicate article's contents, provided the author's and JOTSE

journal's names are included. It must not be used for commercial purposes. To see the complete licence contents, please visit https://creativecommons.org/licenses/by-nc/4.0/. 